NBER WORKING PAPER SERIES

BANKRUPTCY REFORM AND CREDIT CARDS

\author{
Michelle J. White \\ Working Paper 13265 \\ http://www.nber.org/papers/w13265 \\ NATIONAL BUREAU OF ECONOMIC RESEARCH \\ 1050 Massachusetts Avenue \\ Cambridge, MA 02138 \\ July 2007
}

I am grateful to Jim Hynes, Richard Hynes, Eva-Marie Steiger, Andrei Schleifer, Tim Taylor, and Jeremy Stein for very helpful comments. The views expressed herein are those of the author(s) and do not necessarily reflect the views of the National Bureau of Economic Research.

(C) 2007 by Michelle J. White. All rights reserved. Short sections of text, not to exceed two paragraphs, may be quoted without explicit permission provided that full credit, including $\odot$ notice, is given to the source. 
Bankruptcy Reform and Credit Cards

Michelle J. White

NBER Working Paper No. 13265

July 2007

JEL No. G21,G28,G33,K35

\begin{abstract}
From 1980 to 2004, the number of personal bankruptcy filings in the United States increased more than five-fold, from 288,000 to 1.5 million per year. Lenders responded to the high filing rate with a major lobbying campaign for bankruptcy reform that led to the adoption in 2005 of the Bankruptcy Abuse Prevention and Consumer Protection Act (BAPCPA), which made bankruptcy law much less debtor-friendly. The paper first examines why bankruptcy rates increased so sharply. I argue that the main explanation is the rapid growth in credit card debt, which rose from $3.2 \%$ of U.S. median family income in 1980 to $12.5 \%$ in 2004 . The paper then examines how the adoption of BAPCPA changed bankruptcy law. Prior to 2005, bankruptcy law provided debtors with a relatively easy escape route from debt, since credit card debt and other types of debt could be discharged in bankruptcy and even well-off debtors had no obligation to repay. BAPCPA made this escape route less attractive by increasing the costs of filing and forcing some high-income debtors to repay from post-bankruptcy income. However, because many consumers are hyperbolic discounters, making bankruptcy law less debtor-friendly will not solve the problem of consumers borrowing too much. This is because, when less debt is discharged in bankruptcy, lending becomes more profitable and lenders increase the supply of credit. The paper examines the determinants of an optimal bankruptcy law. It also considers the relationship between bankruptcy law and regulation of lending behavior and discusses proposals that would reduce lenders' incentives to supply too much credit to debtors who are likely to become financially distressed.
\end{abstract}

Michelle J. White

Department of Economics

University of California, San Diego

La Jolla, CA 92093-0508

and NBER

miwhite@ucsd.edu 


\title{
Bankruptcy Reform and Credit Cards
}

\author{
Michelle J. White \\ UCSD and NBER
}

From 1980 to 2004, the number of personal bankruptcy filings in the United States increased more than five-fold, from 288,000 to 1.5 million per year. By 2004, more Americans were filing for bankruptcy each year than were graduating from college, getting divorced, or being diagnosed with cancer. Lenders responded to the high filing rate with a major lobbying campaign for bankruptcy reform that lasted nearly a decade and cost more than $\$ 100$ million. Under the Clinton administration, bankruptcy reform went nowhere, but the Bush administration was more supportive and, in 2005, the Bankruptcy Abuse Prevention and Consumer Protection Act (BAPCPA) went into effect. It made bankruptcy law much less debtor-friendly. Personal bankruptcy filings surged to two million in 2005 as debtors rushed to file under the old law and then fell sharply to 600,000 in 2006.

This paper begins with a discussion of why personal bankruptcy rates rose, and will argue that the main reason is the growth of "revolving debt" - mainly credit card debt. Indeed, from 1980 to 2004, revolving debt per household increased five-fold in real terms, rising from 3.2 to 12.5 percent of U.S. median family income. As of 2003, households that held credit card debt had an average revolving debt level of \$15,600 and the average bankruptcy filer had credit card debt of $\$ 25,000 .{ }^{1}$ Table 1 shows real revolving debt per household and the number of personal bankruptcy filings from 1980 to 2006.

The paper then discusses how the Bankruptcy Abuse Prevention and Consumer Protection Act of 2005 altered the conditions of bankruptcy. Prior to 2005, bankruptcy law provided debtors with a relatively easy escape route and many ended up having their credit card and other debts discharged (forgiven) in bankruptcy. The new bankruptcy legislation made this route less attractive, by increasing the costs of filing and forcing

\footnotetext{
${ }^{1}$ Average debt of households that hold credit card debt is calculated assuming that 76 percent of households have credit cards and 63 percent of cardholders have credit card debt (Johnson, 2005; Laibson et al., 2003). Debt of households in bankruptcy is based on a sample of filings in 2003 (Zhu, 2006).
} 
some debtors to repay from post-bankruptcy earnings.

However, because many consumers are hyperbolic discounters, making bankruptcy law less debtor-friendly will not solve the problem of consumers borrowing too much. After all, when less debt is discharged in bankruptcy, lending becomes more profitable and lenders have an incentive to offer yet more credit cards and larger lines of credit. In fact during the first year that BAPCPA was in effect, revolving debt per household rose at a real rate of $4.6 \%$--higher than the rate of increase in any of the previous five years. The paper considers the balances that need to be struck in a bankruptcy system and how the U.S. bankruptcy system strikes these balances in comparison with other countries. I also consider how bankruptcy policy relates to bank regulation and truth-in-lending laws. The paper concludes by reviewing proposals for changes in regulation of lender behavior that would discourage lenders from supplying too much credit or charging excessively high interest rates and fees.

\section{Why Did Personal Bankruptcy Filings Increase?}

There are two main questions about the causes of bankruptcy filings: Why do people file for bankruptcy? And what caused the U.S. bankruptcy filing rate to increase so dramatically between 1980 and 2004?

\section{Adverse Events}

One set of potential causes of bankruptcy is adverse events, such as job loss, health problems/high medical costs, and divorce, that reduce debtors' incomes or increase their living costs. Some researchers argue that adverse events explain most bankruptcy filings. Using data from surveys of bankruptcy filers, Sullivan et al. (2000) claimed that 67 percent of bankrupts filed because of job loss and Himmelstein et al. (2005) claimed that 55 percent of bankrupts filed because of illness, injury or medical bills. But these findings have been criticized as exaggerated. ${ }^{2}$ Another survey, by the Panel Study of

\footnotetext{
${ }^{2}$ In the latter study, bankrupts were classified as filing due to medical reasons whenever they reported
} 
Income Dynamics (PSID), found evidence that adverse events play a much less important role. In the PSID survey, only 23 percent of bankrupts gave job loss as their primary or secondary reason for filing and 20 percent ga ve illness, injury, or medical costs. An additional 17 percent gave divorce as their primary or secondary reason for filing. ${ }^{3}$ Fay, Hurst and White (2003) used the PSID data to estimate a model of the bankruptcy filing decision that tested the importance of adverse events. They found that households were significantly more likely to file if the household head was divorced in the previous year, but not if the head or spouse lost a job or experienced health problems.

In any case, adverse events do not provide a good explanation for the increase in bankruptcy filings, because they have not become more frequent over time. The unemployment rate was 9.7 percent in 1982, fell to 5.6 percent in 1990, and since then has fluctuated between 4.0 and 7.5 percent. The divorce rate also declined, from 5.2 per 1,000 in 1980 to 3.8 per 1,000 in 2002. Medical costs also can't explain the increase in bankruptcy filings. Out-of-pocket medical expenditures borne by households increased only slightly as a percent of median U.S. family income, from 3.5 percent in 1980 to 3.9 percent in 2005 (Statistical Abstract of the United States, 2007, table 120). The percentage of Americans not covered by health insurance has also remained fairly steady: it was 14.8 percent in 1985, 15.4 percent in 1995, and 15.7 percent in 2004 (Statistical Abstract of the United States, 1990 and 2007, Table 144).

The availability of casino gambling is another possible explanation for the increase in bankruptcy filings: specifically, casinos existed only in Nevada and New Jersey in 1980 but had spread to 33 states by 2000. Barron et al. (2002) found that bankruptcy filing rates were 2.6 percent higher in counties that contained a casino or were adjacent to a county with a casino than in counties that were further from the nearest casino. However the effect was fairly small: if gambling were abolished all over the United States, their model predicts that bankruptcy filings would fall nationally by only 1 percent.

$\$ 1,000$ or more in medical expenses during the previous two years. But the average household with annual income of $\$ 22,000$ - $\$ 40,000$ spends $\$ 2,250$ per year on health care, or $\$ 4,500$ over two years. See Dranove and Millenson (2006).

${ }^{3}$ The PSID conducted a special survey of financial distress and bankruptcy in 1996 (psidonline.isr.umich.edu). 
Sullivan, Warren and Westbrook (2000) also argue that bankruptcy filings increased over time because bankruptcy has become a middle-class phenomenon, so that households in a much larger portion of the income distribution now file. However, surveys show that, since the early 1980's, the median income of bankruptcy filers has fallen rather than risen relative to the U.S. median family income level. Sullivan et al. (1989) found that the median income of filers in 1981 was 70 percent of U.S. median family income that year; while in a later survey, Sullivan et al. (2000) found that the median income of filers in 1991 had fallen to 50 percent of the U.S. median family income level. In the largest and most recent survey, Zhu (2006) found that the median income of filers in 2003 was 49 percent of U.S. median family income level that year. Thus, the evidence suggests that the typical bankrupt has become poorer over time, not more middle class.

\section{From Credit Cards to Rising Bankruptcy Filings}

In the Panel Study of Income Dynamics' survey question asking why households file for bankruptcy, 43 percent of bankruptcy filers gave "high debt/misuse of credit cards" as the ir primary or secondary reason for filing - higher than any other explanation. Similarly, all of the empirical models of the bankruptcy filing decision have found that consumers are more likely to file if they have higher consumer debt. Using cross-section household data, Domowitz and Sartain (1999) found that households are more likely to file as their credit card and medical debt levels increase. Using a panel dataset of credit card accounts, Gross and Souleles (2002) also found that cardholders are more likely to file as their credit card debt increases. In Fay et al.'s (2003) model of bankruptcy filings, households were found to be more likely to file as their financial gain from filing increases--where the financial gain from filing mainly depends on how much debt is discharged in bankruptcy. Since both the Gross and Souleles and Fay et al. studies include time dummies, their results suggest that debt is an important factor in explaining both who files for bankruptcy at any particular point in time and why bankruptcy filings have increased over time.

International comparisons also suggest a connection between credit card debt and bankruptcy filings. Ellis (1998) uses the comparison between the United States and 
Canada to argue for the importance of the credit card debt in explaining the increase in bankruptcy filings. General credit cards were first issued in 1966 in the U.S. and in 1968 in Canada. In Canada, both credit card debt and bankruptcy filings increased rapidly starting in 1969. But in the United States, usury laws in a number of states limited the maximum interest rates that lenders could charge on loans, which held down their willingness to issue credit cards. The result was that bankruptcy filings remained constant throughout the 1970s. But in 1978, the U.S. Supreme Court effectively abolished state usury laws in the Marquette decision ${ }^{4}$ and, after that, both credit card debt and bankruptcy filings increased rapidly in the U.S. ${ }^{5}$ Mann (2006) documents a similarly close relationship between credit card debt and bankruptcy filings in Australia, Japan, and the United Kingdom.

Livshits et al. (2006) use calibration techniques to examine various explanations for the increase in bankruptcy filings since the early 1980s. They find that only the large increase in credit card debt combined with a reduction in the level of the bankruptcy punishment can explain the increase in bankruptcy filings since the early 1980s.

Finally, mortgage debt has also grown rapidly since 1980, although the growth rate of mortgage debt is well below the growth rate of revolving debt. The increase in mortgage debt and the increase in bankruptcy filings are related in several ways: first, homeowners often file for bankruptcy in order to delay mortgage lenders from foreclosing on their homes. Second, although mortgage debt is not discharged in bankruptcy, homeowners may file because having their consumer debt discharged makes it easier for them to pay the ir mortgages. Finally, debtors may file for bankruptcy if lenders have foreclosed, but the house sells for less than the mortgage. In this situation, debtors may be liable for the difference, but the liability can be discharged in

\footnotetext{
${ }^{4}$ In Marquette National Bank of Minneapolis v. First Omaha Services Corp. (435 U.S. 299 [1978]), the U.S. Supreme Court held that states cannot regulate interest rates charged on credit card loans if the lender is an out-of-state bank. After this decision, banks that issue credit cards quickly moved to states such as South Dakota and Delaware that abolished their usury laws. A later decision by the Supreme Court, Smiley v. Citibank (South Dakota), N.A. (517 U.S. 735 [1996]), applied the same argument to state regulation of credit card late fees.

${ }^{5}$ Two additional changes that occurred in the United States in 1978 complicate this picture: the adoption of a new U.S. Bankruptcy Code and the legalization of lawyer advertising, which caused lawyers to begin advertising the availability of bankruptcy. But while these factors could have been responsible for a onetime increase in bankruptcy filings, they are unlikely to explain the steady increase in bankruptcy filings over the past 25 years.
} 
bankruptcy. ${ }^{6}$

Overall, the increase in credit card debt and possibly mortgage debt since 1980 provides the most convincing explanation for the increase in bankruptcy filings in the United States.

\section{The Evolution of Credit Card Markets}

Given the close connection between the expansion in credit card debt and the rise in bankruptcy filings, it's useful to review how markets for credit cards have evolved in recent decades. ${ }^{7}$ Until the 1960 s, consumer credit generally took the form of mortgages or installment loans from banks or credit unions. Obtaining a loan required going through a face-to-face application procedure with a bank or credit union employee, explaining the purpose of the loan, and demonstrating ability to repay. Because of the costly application procedure and the potential embarrassment of being turned down, these loans were generally small and went only to the most credit-worthy customers. Consumers also obtained installment loans from stores and car dealers to purchase durable goods and cars. ${ }^{8}$ This pattern began to change with the introduction of credit cards in 1966, since credit cards provided unsecured lines of credit that consumers could use at any time for any purpose. The earliest credit cards were issued by banks where consumers had their checking or savings accounts. Because most states had usury laws that limited maximum interest rates, lenders offered credit cards only to the most creditworthy consumers and card use therefore grew only slowly. But after the Marquette decision in 1978, credit card issuers could charge higher interest rates and they expanded in states where low interest rate limits had previously made lending unprofitable.

Over time, the development of credit bureaus and computerized credit scoring models changed credit card markets, because lenders could obtain information from

\footnotetext{
${ }^{6}$ Real mortgage debt per household tripled between 1980 and 2006, while real revolving debt per household grew by a factor of 4.6 over the same period. See Berkowitz and Hynes (1999) and Lin and White (2001) for discussion of the relationship between mortgage debt and homeowners' gain from filing for bankruptcy.

7 See Ausubel (1997), Evans and Schmalensee (1999), Moss and Johnson (1999), Peterson (2004), and Mann (2006) for discussion and history of credit cards.

${ }^{8}$ Although less consumer credit was available prior to credit cards, some consumers nonetheless ended up in financial distress. See Caplovitz (1974).
} 
credit bureaus about individual consumers' credit records and could therefore offer credit cards to consumers who had no prior relationship with the lender. Lenders first offered credit cards to consumers who applied by mail, and then began send ing out pre-approved card offers to lists of consumers whose credit records were screened in advance. These innovations reduced the cost of credit both by eliminating the face-to-face application process and by allowing lenders to expand nationally, which increased competition in local credit card markets. From 1977 to 2001, the proportion of U.S. households having at least one credit card rose from 38 to 76 percent (Durkin, 2000). Over the same period, revolving credit increased from 16 to 37 percent of non- mortgage consumer credit, which means that credit card loans tended to replace other forms of consumer credit.

This shift from installment to revolving loans meant dramatic changes in the terms of consumer debt. Secured and installment loans carry fixed interest rates and fixed repayment schedules. Credit card loans, in contrast, allow lenders to change the interest rate at any time and allow debtors to choose how much they repay each month, subject to a low minimum payment requirement. Consumers who choose to repay in full each month use credit cards only for transacting; while those who repay less than the full amount due each month use credit cards for both transacting and borrowing. The former group receives an interest-free loan from the date of the purchase to the due date of the bill, while the latter pays interest from the date of purchase. If consumers pay late or borrow close to their credit limits, then lenders raise the interest rate to a penalty range. Lenders also charge fees when debtors pay late or exceed their credit limits.

Credit card issuers compete heavily for new customers by mailing out unsolicited, pre-approved credit card offers: in 2001, the average U.S. household received 45 of these offers (Bar-Gill, 2004). Over time, competition among issuers has led them to offer increasingly favorable introductory terms and increasingly onerous post-introductory terms. The favorable introductory terms encourage consumers to accept new credit cards - they include zero annual fees, cash back or frequent flier miles, and low or zero introductory interest rates on purchases and balance transfers. Once consumers accept new cards, the rewards programs encourage them to spend more and low minimum monthly payments encourage them to borrow. The format of the monthly bills also encourages consumers to borrow, since minimum payments are often shown in large type 
while the full amount due is shown in small type. Minimum monthly payments are low - typically the previous month's interest and fees plus one percent of the principlewhich means that debtors who pay only the minimum each month still owe nearly half of any amount borrowed after five years. After the introductory period, terms become much more onerous: the average credit card interest rate is 16 percent, interest rates rise to 24 to 30 percent if debtors pay late, and penalty fees for paying late or exceeding the credit limit are around $\$ 35$. This pattern of credit card pricing implies that issuers make losses on new accounts and offset the ir losses with profits on older accounts.

Credit card issuers have also expanded their high-risk operations by lending to consumers who have lower incomes, lower credit scores, and past bankruptcy filings. The percentage of households in the lowest quintile of the income distribution who have credit cards rose from 11 percent in 1977 to 43 percent in 2001 (Durkin, 2000; Johnson, 2005). A study in the early 1990s found that three-quarters of bankrupts had at least one credit card within a year after their bankruptcy filings (Staten, 1993). ${ }^{9}$

The shift of consumer debt from installment debt to credit card debt, combined with the pattern of credit card pricing, have made consumers' debt burdens much more sensitive to changes in income. When consumers' incomes are high, they are likely to pay their credit card bills in full and therefore their debt burden is low and they pay little or no interest. But when their incomes decline, they are likely to pay late or pay the minimum on their credit cards, so that their debt burdens increase and they pay much more in interest and fees. Although credit cards allow consumers to smooth consumption when their incomes fall, the cost of doing so is extremely high and may cause debtors to be in permanent financial distress.

\section{Rational Consumers versus Hyperbolic Discounters}

Considerable recent research suggests that consumers fall into two groups based on their attitudes toward saving: rational consumers versus hyperbolic discounters. Rational consumers apply the same discount rate over all future periods. Hyperbolic discounters, in contrast, want to save more starting at some point in the future, but in the

\footnotetext{
${ }^{9}$ Interest rates on credit card loans have been high relative to lenders' cost of funds since the $1980 \mathrm{~s}$ (Ausubel, 1991 and 1997; Bar-Gill, 2004).
} 
present they always prefer to consume rather than save (Laibson, 1997). Thus a hyperbolic discounter is like a person who always wants to start dieting tomorrow, but never today. Prior to the development of credit cards, the difference between rational consumers and hyperbolic discounters was less important, because consumers' borrowing opportunities were limited. But as credit card loans have become more widely available, borrowing opportunities have increased and the difference has become more important.

Laibson et al. (2003) found in simulations that hyperbolic discounters borrow more than three times as much as rational consumers, regardless of whether both types pay the same interest rate or hyperbolic discounters pay higher rates. Applying these results to credit card pricing suggests that rational consumers are more likely to use credit cards purely for transacting, while hyperbolic discounters are more likely to use them for borrowing. Also, allowing consumers to choose how much to pay on their credit cards each month makes it more likely that hyperbolic discounters will accumulate high credit card debt, because each month they resolve to start paying off their debt, but when the next bill arrives they consume too much and postpone repaying until the following month. Because hyperbolic discounters borrow more than rational consumers, they are also more likely to pay high credit card interest rates and penalty fees. Thus, hyperbolic discounters are likely to accumulate steadily increasing credit card debt, while rational consumers are more likely to avoid accumulating debt by repaying in full.

Gross and Souleles (2002) provide evidence supporting the hyperbolic discounting model in the context of credit cards: they find that cardholders increase their borrowing in response to interest rate reductions by more than they reduce their borrowing in response to interest rate hikes-which suggests why lenders offer low introductory interest rates and charge high rates later on In the bankruptcy context, a 2006 study of debtors who sought credit counseling prior to filing for bankruptcy found that two-thirds were in financial difficulties because of "poor money management/excessive spending," while only $31 \%$ who were in difficulties because of loss of income or medical bills (National Foundation for Credit Counseling, 2006). These results suggest that most debtors in financial distress are hyperbolic discounters rather than rational consumers who have experienced adverse events. 


\section{U.S. Bankruptcy Law}

U.S. bankruptcy law has traditionally had two separate personal bankruptcy procedures named, after parts of the bankruptcy law, Chapter 7 and Chapter 13. Under both procedures, creditors must immediately terminate all efforts to collect from the debtor-including letters, telephone calls, garnishment of wages, and lawsuits. Most consumer debt is discharged in bankruptcy, but most tax obligations, student loans, alimony and child support obligations, debts incurred by fraud, and some credit card debt incurred for luxury purchases or cash advances are not. Mortgages, car loans, and other secured debts are not discharged in bankruptcy, but filing for bankruptcy generally allows debtors to delay creditors from foreclosing or repossessing assets. The main difference between the two Chapters is that Chapter 7 only requires bankrupts to repay from their assets and Chapter 13 only requires them to repay from future income. Prior to the Bankruptcy Abuse Prevention and Consumer Protection Act of 2005, debtors were allowed to choose between the two.

\section{Bankruptcy Law Before 2005}

The most commonly used procedure before the 2005 law was Chapter 7. Under it, bankrupts must list all their assets. Bankruptcy law makes some of these assets exempt, meaning that they are off-limits to creditors and the debtor is allowed to keep them. Asset exemptions are determined by the state in which the debtor lives. Most states exempt debtors' clothing, furniture, "tools of the trade," and some equity in a vehicle. In addition, nearly all states have homestead exemptions for equity in owneroccupied homes and these vary from a few thousand dollars to unlimited in six states, including Texas and Florida. Many states also allow debtors an unlimited homestead exemption if they are married, only one spouse files for bankruptcy, and they own their homes as "tenants by the entirety." Other states allow debtors to exempt assets by placing them in a trust before filing. Elias (2005) provides a list of asset exemptions by state. Under Chapter 7, debtors must use their non-exempt assets to repay creditors, but they are not obliged to use any of their future income to repay.

Under the alternative procedure--Chapter 13, bankrupts are not obliged to repay 
from assets, but they must use part of their post-bankruptcy income to repay. Before the 2005 law, there was no pre-determined income exemption; instead, debtors who filed under Chapter 13 proposed their own repayment plans. They often proposed to repay an amount equal to the value of their non-exempt assets in Chapter 7 or, if all of their assets are exempt, then they proposed to repay a token amount. Debtors were not allowed to repay less than the value of their non-exempt assets and, since they could file under Chapter 7, they had no incentive to offer more. Only the approval of the bankruptcy judge--not creditors--was required.

The costs of filing for bankruptcy were low--about $\$ 600$ in Chapter 7 and $\$ 1,600$ in Chapter 13 as of 2001 (Flynn and Bermant, 2002). The punishment for bankruptcy was also low--bankrupts' names are made public and the bankruptcy filing appears on their credit records for 10 years. Their access to credit falls and they may not be hired for certain types of jobs. In addition, bankrupts were not allowed to file again under Chapter 7 for six years (but they were allowed to file under Chapter 13 as often as every six months).

In order to induce more bankrupts to file under Chapter 13 and repay from future income, U.S. bankruptcy law allowed additional debt to be discharged under Chapter 13. Debtors' car loans could be discharged to the extent that the loan principle exceeded the market value of the car. Also, debts incurred by fraud and cash advances obtained shortly before filing could be discharged in Chapter 13, but not in Chapter 7. These features were known as the Chapter 13 "super-discharge." Some bankrupts took advantage of the super-discharge by filing first under Chapter 7, where most of their debts were discharged, and then converting their filings to Chapter 13, where they proposed a plan to repay part of the additional debt covered by the super-discharge. This two-step procedure, known as filing a "Chapter 20," increased debtors' financial gain from bankruptcy relative to filing under either procedure by itself.

Overall, these features made U.S. bankruptcy law very pro-debtor. Since debtors could choose between Chapters 7, 13, and "20," they picked the procedure that maximized their gain. Debtors could gain from filing under Chapter 7 regardless of how high their incomes were and they could also gain from filing under Chapter 7 with high 
assets, if they planned in advance to convert their assets from non-exempt to exempt. For example, debtors could move to a state with a high asset exemption and use their assets to buy a large house, thereby converting non-exempt assets into exempt home equity.

Around three-quarters of all bankruptcy filers used Chapter 7 (Flynn and Bermant, 2003). Most debtors who filed under Chapter 13 did so because their gains were even higher than under Chapter 7.

Indeed, prior to the adoption of BAPCPA, debtors' obligation to repay in bankruptcy bore little relationship to their ability-to-pay. Using data from the early 1990s, I estimated that at least one-sixth of U.S. households could gain financially from filing for bankruptcy under pre-BAPCPA Chapter 7 and the proportion increased to as high as one-half if households followed simple strategies to shelter additional assets before filing. Debtors' gain from filing for bankruptcy also increased as their incomes rose, since higher-income debtors usually had more debt that would be discharged, but still had no obligation to repay in bankruptcy (White, 1998).

By providing consumers with an easy escape route from debt, U.S. bankruptcy law encouraged consumers to borrow and encouraged debtors to behave strategically and to file for bankruptcy even when they could afford to repay. It also penalized debtors who repay by causing lenders to raise interest rates and reduce credit availability (Gropp, Scholz, and White, 1997). But while a number of rich and famous people made headlines by filing for bankruptcy, most bankrupts were not well-off-at least according to the information they provide in their bankruptcy filings. ${ }^{10}$ In Zhu's (2006) sample of bankruptcy filings in 2003 , only 2.5 percent had annual incomes above $\$ 70,000$.

\section{The Bankruptcy Abuse Prevention and Consumer Protection Act}

The Bankruptcy Abuse Prevention and Consumer Protection Act (BAPCPA) of 2005 made several major changes to bankruptcy law. First, it abolished the right of

\footnotetext{
${ }^{10}$ Among the high-profile people who have filed for bankruptcy are Governor of Texas John Connally, actor Burt Reynolds, corporate raider Paul Bilzerian, actresses Debbie Reynolds and Kim Basinger, rapper MC Hammer, singer Merle Haggard, U.S. baseball commissioner Bowie Kuhn, and boxer Mike Tyson (www.bankruptcy-usa.info/famous-bankruptcies.html). In contrast, O.J. Simpson would not gain from filing for bankruptcy, because debts resulting from legal judgments due to "willful or malicious acts" are not dischargeable in bankruptcy (Elias, 2006). Simpson presumably moved to Florida because state asset exemptions apply both in and out of bankruptcy, so that Florida's unlimited homestead exemption protects his assets from creditors' claims even though he has not filed.
} 
debtors to choose between Chapters 7 and 13. Second, debtors are no longer allowed to propose their own Chapter 13 repayment plans. Third, BAPCPA greatly raised bankruptcy costs by imposing many new requirements on debtors and their lawyers. Let's discuss these in turn.

The first change, abolishing the right of debtors to choose between Chapter 7 and Chapter 13, may be the most significant. Under the Bankruptcy Abuse Prevention and Consumer Protection Act, debtors must pass a new "means test" to file under Chapter 7. Debtors qualify for Chapter 7 if their monthly family income averaged over the six months prior to filing is less than the median monthly family income level in their state, adjusted for family size. To get a flavor of what this rule means, median family income for three-person families is currently about $\$ 64,000$ in California and New York, $\$ 75,000$ in Massachusetts, and \$48,000 in West Virginia. Depending on their debt levels, some debtors are allowed to file under Chapter 7 with average monthly family income that exceeds the state median income level, as long as their monthly "disposable income" (defined below) is no higher than $\$ 166$ per month. Thus, the 2005 law prevents some debtors from taking advantage of the unlimited income exemption in Chapter 7 , since they cannot file under Chapter 7 if their incomes are too high. Debtors who fail the means test must file under Chapter 13 if they file for bankruptcy at all.

Otherwise, Chapter 7 itself remains essentially unchanged. State-specific asset exemption levels remain in effect and Chapter 7 filers are only obliged to use their nonexempt assets to repay. But the Bankruptcy Abuse Prevention and Consumer Protection Act imposed new restrictions on some of the strategies that debtors previously used to shelter high assets in bankruptcy. For example, if debtors move to a state with a higher homestead exemption and file for bankruptcy within two years, they must now use their old state's homestead exemption. If debtors purchase a home and then file for bankruptcy within $2 \frac{1}{2}$ years, the homestead exemption is capped at $\$ 125,000$. If debtors convert non-exempt assets into home equity by paying down their mortgages or renovating their homes, they must do so at least $31 / 3$ years or 10 years, respectively, before filing---otherwise the additional home equity will not be exempt (Martin, 2006). On the other hand, BAPCPA added a generous new Chapter 7 asset exemption for up to $\$ 1,000,000$ in tax-sheltered individual retirement accounts (up to $\$ 2,000,000$ for married 
couples who file for bankruptcy). Although this new exemption is very generous, few debtors are likely to benefit from it, because they cannot shift large amounts of assets into retirement accounts just before filing.

The second major change under the Bankruptcy Abuse Prevention and Consumer Protection Act abolishes debtors' right to propose their own Chapter 13 repayment plans and substitutes a uniform procedure that determines their repayment obligations. Debtors must now use 100 percent of their "disposable income" for five years to repay, where BAPCPA defines disposable income as the difference between debtors' average monthly family income during the six months prior to filing and a new income exemption. The income exemption is based on Internal Revenue Service procedures for collecting from delinquent taxpayers and, for each debtor, it determines an allowance for living expenses. Debtors receive an allowance for housing and utilities that varies by metropolitan area; for example it covers expenditures up to a maximum of $\$ 986$ per month in Charleston, West Virginia, and \$1,763 per month in Boston, Massachusetts. They also receive a transport allowance that depends on the number of vehicles the debtor's family owns (up to two) and local gasoline prices. For two-car families, the allowance in Boston is $\$ 1,185$ per month. Debtors also receive an allowance for food, clothing and personal care that varies with income. For three-person families, the maximum allowance ranges from $\$ 830$ per month if family income is below $\$ 10,000$ per year to $\$ 1,368$ per month if family income exceeds $\$ 70,000$ per year. A number of other types of expenditure are added to the income exemption, including the full amount of debtors' expenditures on taxes (except property taxes); mandatory retirement contributions; child support payments; education expenses up to $\$ 125 /$ month per child; uninsured health care costs; child care costs; the cost of term life, disability, ho meowners', and health insurance; contributions to charity; contributions to the care of elderly or disabled relatives; the costs of telecommunications and home security; and the cost of repaying secured debt. For details of the means test and the income exemption, see <http://www.usdoj.gov/ust/eo/bapcpa/meanstesting.htm>. All of these components are added together to determine each debtor's income exemption.

Third, BAPCPA greatly raised bankruptcy costs. Debtors are now required to take a credit counseling course before they file and a financial management course before 
their debts are discharged. They must file detailed financial information with the bankruptcy court, including copies of their tax returns for the past four years (which may mean they have to prepare tax returns that were never filed). Bankruptcy lawyers must certify the accuracy of all the information filed. Lawyers can be fined and debtors' bankruptcy filings can be dismissed if any information is found to be false or inaccurate. Filing fees have also increased. These new requirements raise debtors' out-of-pocket costs of filing to around $\$ 2,500$ for Chapter 7 and \$3,500 for Chapter 13 (Elias, 2005), plus the costs of the two courses and preparation of tax returns.

BAPCPA also abolished the Chapter 13 "super-discharge" and increased the amount of credit card debt that is not discharged in bankruptcy. It increased the length of Chapter 13 repayment plans from as little as three years to a mandatory five years. Finally it increased the minimum time that must elapse between bankruptcy filings: from six to eight years for Chapter 7 filings; from six months to two years for Chapter 13 filings; and from no minimum to four years for a Chapter 7 filing followed by a Chapter 13. These changes mean that fewer debtors are eligible for bankruptcy at any given time.

Overall, the adoption of Bankruptcy Abuse Prevention and Consumer Protection Act raised bankruptcy costs, lowered the amount of debt discharged in bankruptcy, lowered the income exemption, raised the amount of post-bankruptcy income that debtors must use to repay, and increased the repayment period. There is now a maximum income level above which debtors no longer gain from filing, since the BAPCPA means test prevents them from filing under Chapter 7 and forces them to repay from postbankruptcy income. BAPCPA also lowered asset exemptions for some debtors who have high home equity and raised asset exemptions for a few debtors who have large retirement accounts. Except for the last of these points, all of these changes made U.S. bankruptcy law more pro-creditor.

However, the stringency of these changes should not be exaggerated. Although there is now a maximum income level above which debtors do not gain from filing for bankruptcy, the maximum is quite high and debtors can raise it by planning strategically before filing. For example, debtors who have experienced income fluctuations can pass the means test at higher income levels by filing when their average income over the 
previous six months is minimized. Because social security income is excluded from the means test, older debtors qualify for Chapter 7 at higher income levels. Entrepreneurs can file under Chapter 7 regardless of how high their incomes are, since debtors who have primarily business debts are allowed to bypass the means test and file under Chapter 7. Debtors can also pass the means test at higher income le vels by changing their expenditures in ways that raise the income exemption, such as by buying a car with a car loan or obtaining a new mortgage before filing, or spending more on child care, insurance, or charitable contributions. In sample calculations (White, 2007), I found that debtors could pass the means test with family incomes at least twice their state's median income level, which means that debtors can still gain financially from filing for bankruptcy even if their family income level is in the top decile of the U.S. income distribution. Debtors who fail the means test can also reduce their obligation to repay in Chapter 13 by working less during the six months prior to filing-for example, a reduction in work effort that reduces debtors' average monthly income by $\$ 1$ prior to filing costs them $\$ 6$, but reduces their repayment obligation in Chapter 13 by $\$ 1$ per month for 5 years, or $\$ 60$.

Overall, the adoption of a means test under the Bankruptcy Abuse Prevention and Consumer Protection Act of 2005 made debtors' obligation to repay in bankruptcy more closely related to their ability-to-pay. However U.S. bankruptcy law still allows debtors to gain from filing for bankruptcy even with fairly high asset and income levels. Despite all the changes under BAPCPA, U.S. bankruptcy law remains more pro-debtor than bankruptcy law in other country. But BAPCPA harms the worst-off debtors, because many of them will be unable to pay the new high bankruptcy costs.

\section{Directions for the Next Bankruptcy Reform}

Bankruptcy law was greatly in need of reform before 2005, because it allowed debtors to escape their debts even if they had high assets and high income. But although the 2005 law is barely on the books, it's already possible to discern the outlines of the 
next set of bankruptcy reforms that is likely to be needed.

The difficulty comes in two reinforcing parts. First, although bankruptcy law in the U.S. remains more pro-debtor than in any other country, some of the debtors who are most in need of bankruptcy-provided debt relief will be unable to file because they cannot afford to pay the higher costs of bankruptcy, including lawyers' fees, filing fees, and the other costs of filing. In addition, because BAPCPA changed bankruptcy law in a procreditor direction, credit card issuers responded by expand ing the supply of credit. But more credit card loans combined with reduced access to debt relief in bankruptcy seems certain to result in severe financial distress for at least some debtors.

This problem is particularly severe for hyperbolic discounters. As discussed above, hyperbolic discounters tend to be worse off than rational consumers, since they have higher debt, lower assets, and-because they invest less in human capital—lower incomes. In the post-BAPCPA environment, hyperbolic discounters will be more tempted by the up-front rewards from credit card lenders, and will borrow even more. But hyperbolic discounters are also likely to ignore the changes in bankruptcy law until after they are in financial distress. At that point, many of them will discover that they are unable to file, either because they cannot afford the costs of bankruptcy or because they have filed under Chapter 7 within the past eight years. Also once in bankruptcy, hyperbolic discounters are more likely to have difficulty providing the detailed information that the new bankruptcy law requires, including four years' of past tax returns that they may not have filed originally. The new BAPCPA education mandatesfor credit couns eling and financial management — could theoretically help hyperbolic discounters learn to control their spending. But in practice, education is likely to have little effect, since debtors are only required to get it after they are in financial distress and considering bankruptcy.

Any delay by debtors in filing for bankruptcy, even if only for a few months, benefits lenders by giving them additional time to harass debtors with collection calls, persuade them to make payments on credit card loans even though the loans would be discharged in bankruptcy, and collect part of their earnings using wage garnishment. Indeed, early evidence suggests that credit card issuers have benefited from the adoption of the Bankruptcy Abuse Prevention and Consumer Protection Act. Credit card issuers' 
charge-off rates fell from around 6 percent before the adoption of BAPCPA to 3 percent afterwards, while their mark-up over costs remained constant. Also the share prices of publicly-traded third party debt collectors-firms that buy charged-off credit card loans and attempt to collect from debtors-increased by 17 percent relative to the market when BAPCPA was adopted (Ashcraft, Dick, and Morgan, 2006).

To understand the sorts of reforms that are likely to be useful, let's first review the underlying functions of bankruptcy law, and then consider how the more pro-creditor bankruptcy laws of other countries function. With that background, we can then suggest some potentially useful reforms both of bankruptcy law and of complementary laws and rules related to banking and truth-in- lending.

\section{The Underlying Functions of Bankruptcy Law}

Bankruptcy law must balance two conflicting functions. First, bankruptcy provides debtors with a form of consumption insurance. Consumers benefit from being able to borrow so that they can smooth consumption over the life cycle, but their future incomes and expenses are uncertain. If income turns out to be particularly low and/or expenses particularly high when the loans come due, then repaying could harm debtors and their families by drastically reducing their consumption. Discharging debt in bankruptcy increases debtors' consumption when it is low and therefore allows them to smooth consumption over states of nature as well as over time. Debtors pay a "premium" for this implicit consumption insurance in the form of higher interest rates, because the insurance raises the risk of default.

The objective of providing consumption insurance has grown in importance over time, as evidenced by the expansion in most countries' government-provided social safety nets. Having a bankruptcy procedure that discharges debt when debtors' abilityto-pay is low increases the overall level of consumption insurance by forcing lenders to provide some insurance privately (Posner, 1995). Bankruptcy-provided consumption insurance may not be needed if the government itself provides a generous social safety net. But having it forces lenders to bear part of the cost of consumption insurance and 
prevents credit markets from undermining the social safety net.

Second, bankruptcy discourages default by punishing those who file. Debtors who default and file for bankruptcy impose a negative externality on future borrowers, since default causes lenders to ration credit and raise interest rates. A harsh bankruptcy policy reduces this externality by reducing moral hazard on the part of debtors, including debtors borrowing without intending to repay, borrowing without considering whether they have the ability to repay, and working less so that their ability-to-pay falls. But punishing bankrupts harshly also increases moral hazard on the part of lenders, because lenders have a stronger incentive to attract borrowers with attractive introductory offers, to lend too much to risky borrowers, and to charge very high fees and interest rates.

In the past, credit was scarce and expensive, so that the main purpose of bankruptcy law was to punish defaulters and to distribute debtors' assets among creditors. ${ }^{11}$ Loans were made only to the most credit-worthy borrowers-mainly merchants and landowners-and those who went bankrupt were assumed to have either engaged in fraud or recklessly disregarded their moral obligation to repay. Punishments therefore were severe. Among the punishments that have been used in various countries at various times are the death penalty, selling bankrupts and their children into slavery, forcing bankrupts to become indentured servants of their creditors, putting them in prison, flogging, branding, and cutting off their hands, exiling them, and publicly shaming them in various ways (Efrat, 2002). In addition, bankrupts were forced to give up all of their assets to repay creditors and there was no debt discharge, so they remained liable to repay for the rest of their lives.

As the cost of lending fell, the death penalty, slavery, prison, and other severe punishments for bankruptcy were abolished in most places and filing for bankruptcy is no longer considered to be a crime. The U.S. states and England abolished prison as a penalty for default during the $19^{\text {th }}$ century. The development of debt discharge and of asset exemptions also reduced the severity of punishment for bankruptcy. In England, a

\footnotetext{
11 Having a procedure to allocate debtors' assets among multiple creditors reduces creditors' incentive to race to be first to collect. See White (2007) for discussion.
} 
short-lived bankruptcy statute adopted in 1706 was the first to allow some discharge of debt and, prior to American independence, some of the colonies had procedures for discharging debt. The first U.S. bankruptcy law, adopted in 1800, also allowed for debt discharge if a majority of creditors consented. Asset exemptions appeared as early as the 1790s, when Virginia and other southern states adopted them in order to protect local landowners from their northern creditors. Exemptions became more widespread and more generous in the nineteenth century, when states in the south and west used them to compete for migrants (Coleman, 1974; Mann, 2002).

Finally, another aspect of bankruptcy law is that it affects workers' incentives to become self-employed. Owners of small businesses are personally liable for their business debts (this is often the case even if the businesses are incorporated), so that they end up with high debts if their businesses fail. A pro-debtor bankruptcy law encourages self-employment by discharging both business and personal debts in bankruptcy, by having high exemptions for assets and future income, and by having low bankruptcy costs and punishment. These provisions encourage even risk-averse workers to go into business because, if the ir businesses fail, they will not have to use their future income to repay past business debts and they may be able to keep their homes. Conversely, a procreditor bankruptcy law discourages workers from taking on the risk of selfemployment. $^{12}$

\section{Bankruptcy Law Tradeoffs in Other Countries}

How do different countries make the bankruptcy tradeoff between providing consumption insurance to debtors and punishing default? In comparing bankruptcy policies, it is useful to think of such policies as summed up by seven parameters: the amount of debt discharged, the asset exemption, the income exemption, the fraction of debtors' future income above the exemption that must be used to repay, the length of the repayment obligation, bankruptcy costs, and the bankruptcy punishment. A bankruptcy

\footnotetext{
${ }^{12}$ Fan and White (2003) show empirically that more workers choose self-employment in U.S. states that have higher homestead exemptions.
} 
policy is more pro-debtor if the amount of debt discharged or the exemption levels increase, or if bankruptcy costs, the bankruptcy punishment, the length of the repayment period, or the fraction of non-exempt income that must be used to repay fall. Table 2 summarizes these parameters for U.S. personal bankruptcy law both before and after the adoption of BAPCPA. Among other countries, some have no bankruptcy laws at all and some only allow business owners and corporations to go bankrupt. Table 3 summarizes bankruptcy law in four countries that allow consumers to file for bankruptcy-France, Germany, Canada, and England/Wales. ${ }^{13}$

The values of the bankruptcy parameters differ considerably across the four countries. France's bankruptcy law is the most pro-creditor: exemptions for assets and income are very low, bankrupts must use nearly all of their non-exempt income to repay, and the repayment obligation lasts for eight to ten years. Bankruptcy judges can penalize debtors for low effort during the repayment period by denying the discharge. This means that bankrupts are reduced to a poverty-level standard of living and have little incentive to work for a long period of time. However, judges can also soften the procedure by giving debtors an immediate discharge on the grounds that they cannot repay their debts even over 10 years. Judges can also discharge additional debt if they feel that lenders made loans to debtors who were already "over-indebted." Because debtors' costs of filing are very low, they have an incentive to default on their repayment plans and file for bankruptcy again, since a new filing gives them a new chance of having their debts discharged immediately (Kilborn, 2005). Thus while French bankruptcy procedure is very pro-creditor, a small percentage of French bankrupts receive a more lenient treatment similar to Chapter 7 in the U.S.

Germany's bankruptcy procedure is similar to France's but the repayment period is six years rather than eight to ten. Debtors who exhibit good behavior by working or seeking work are allowed to keep 10 percent of their non-exempt income during the $4^{\text {th }}$ year of the repayment plan and 15 percent during the $5^{\text {th }}$ year. However there is no

\footnotetext{
${ }^{13}$ China, Turkey, Italy, Mexico and Argentina are examples of countries that allow only business owners to go bankrupt. Chile and the Czech Republic are examples of countries that allow individuals to file for bankruptcy, but do not discharge debt in bankruptcy (Efrat, 2002). In Germany, the first bankruptcy law that allowed individual consumers to have debt discharged in bankruptcy was adopted in 1999.
} 
procedure that allows for immediate discharge of debt; all bankrupts in Germany must complete a repayment plan before receiving a discharge even if they earn too little to repay anything (Kilborn, 2004). Bankruptcy laws in England/Wales and in Canada are more pro-debtor than those in France or Germany. In England/Wales, debtors are only obliged to use 30 to 50 percent of their non-exempt income to repay and the repayment period lasts three years. However Britain imposes shaming punishments on bankrupts, who are barred from borrowing money, managing a business, working as a lawyer, or holding public office for 3 years after filing. In Canada, debtors must use 50 percent of their non-exempt income to repay and the repayment period lasts between nine months and three years. Like the U.S., Canada has homestead exemptions that vary across provinces - they are generally lower than homestead exemptions in the U.S., but higher than those in the other countries. Overall, U.S. bankruptcy law remains more debtorfriendly than bankruptcy law in any of the four countries, even after the adoption of

\section{BAPCPA.}

\section{Adjusting Bankruptcy Law}

As a starting point for thinking about adjustments to bankruptcy law, consider a world of rational consumers, who borrow only to smooth consumption. These consumers sometimes suffer adverse shocks. The interest rates that they pay for borrowing include a risk premium for the defaults that inevitably occur following adverse events.

In this setting, bankruptcy-provided consumption insurance costs debtors more than its fair price, because debtors not only compensate lenders for default by paying higher interest rates but, in addition, they must pay bankruptcy costs and bear the bankruptcy punishment whenever they file. As a result, if debtors are risk neutral, then they prefer not to have a bankruptcy system at all; while if they are risk-averse, they prefer to have a bankruptcy system and the ir preferred bankruptcy system is more prodebtor as the degree of risk-aversion increases. This suggests that if most debtors are risk averse, the optimal bankruptcy policy is to provide some consumption insurance, with the optimal level of consumption insurance increasing as debtors become more risk-averse (Wang and White, 2000). Additional considerations that affect the optimal bankruptcy policy are that it should provide a higher level of consumption insurance in countries that 
want to encourage self-employment and a lower level of consumption insurance in countries that provide more comprehensive social safety nets.

When debtors are hyperbolic discounters, the determination of optimal bankruptcy policy becomes more complex. Remember, hyperbolic discounters have dynamically inconsistent preferences; they prefer to borrow today and start saving tomorrow - but tomorrow never comes. This means that their preferences concerning bankruptcy are also inconsistent. When hyperbolic discounters focus on their desire to borrow and consume today, they prefer to have no bankruptcy system or a very procreditor bankruptcy system, because they can borrow the most under such a system. But if and when hyperbolic discounters focus on their desire to save, they prefer a bankruptcy system that forces them to save by restricting their ability to borrow today. These sophisticated hyperbolic discounters prefer a very pro-debtor bankruptcy system, since lenders ration credit more tightly as the bankruptcy system becomes more pro-debtor and may not be willing to lend at all if the bankruptcy system is very pro-debtor. Thus whether hyperbolic discounters prefer a pro-debtor or pro-creditor bankruptcy system depends on whether or not they recognize their tendency to borrow too much and favor a bankruptcy system that gives them more control over their own behavior.

Another issue that affects bankruptcy law is whether creditors can tell if particular debtors are rational consumers versus hyperbolic discounters. Creditors can identify many individuals' types by their past borrowing behavior, which they learn from credit records. But creditors probably cannot identify all debtors' types and, if so, then rational consumers cross-subsidize hyperbolic discounters in the loan market because rational consumers are less likely to default. This means that rational consumer pay a risk premium for borrowing that exceeds their true default risk, while hyperbolic discounters pay a risk premium that is lower than their true default risk. As a result, rational consumers prefer to borrow less and, since they benefit less from bankruptcy, they prefer a more pro-creditor bankruptcy system. In contrast, hyperbolic discounters may prefer a more pro-debtor bankruptcy system, although their preferences change less since their demand for credit is less responsive to changes in the interest rate. ${ }^{14}$

\footnotetext{
${ }^{14}$ In simulations, Laibson et al. (2003) found that rational consumers borrow slightly more when a bankruptcy system is introduced, but the borrowing behavior of hyperbolic discounters does not change.
} 
A variety of bankruptcy policy parameters have different effects on rational cons umers versus hyperbolic discounters. For example, an increase in the asset exemption provides debtors with additional consumption insurance, but only if the have non-exempt assets. Since rational consumers tend to have more assets than hyperbolic discounters, this change mainly benefits rational consumers. Similarly, an increase in the income exemption or a reduction in the proportion of non-exempt income that debtors must use to repay provides additional consumption insurance, but only to debtors whose have non-exempt income. If rational consumers tend to have higher incomes than hyperbolic discounters, then these changes also mainly benefit rational consumers.

On the other hand, raising the income exemption reduces the distortion to debtors' post-bankruptcy work incentives, while an increase in the asset exemption has little or no effect on debtors' work incentives. This suggests that the income exemption should be relatively high, while the asset exemption should be relatively low. If hyperbolic discounters tend to have a higher ratio of income to assets than rational consumers, then this policy prescription benefits them. Similarly, an increase in the amount of debt discharged benefits hyperbolic discounters more than it benefits rational consumers, since hyperbolic discounters have more debt. And reductions in bankruptcy costs or the bankruptcy punishment also benefit hyperbolic discounters more than rational consumers, because hyperbolic discounters file for bankruptcy more often.

Overall, an economically efficient bankruptcy system should have a fairly low asset exemption level, since a higher asset exemption mainly benefits well-off bankruptcy filers. It should also have low bankruptcy costs and a low bankruptcy punishment, since low values of these variables provide additional consumption insurance to the worst-off bankrupts. The income exemption should be higher if debtors are more risk averse or if debtors' work effort responds more strongly to the exemption level. Bankruptcy policy should be more pro-debtor if hyperbolic discounters wish to control their borrowing behavior.

However a problem with bankruptcy policy is that it is not very effective in reducing borrowing by hyperbolic discounters, since these debtors are likely to ignore the provisions of bankruptcy law until after they are in financial distress. This means that, if

(They did not examine the effects of making the bankruptcy system more or less pro-debtor.) 
the goal is to reduce borrowing by hyperbolic debtors, a more effective approach would be to focus on lenders' incentives. Under current U.S. bankruptcy law, lenders have an inefficiently high incentive to lend to borrowers who already are heavily indebted, since all unsecured loans are treated equally in bankruptcy. One approach to reform is to vary the treatment of particular loans in bankruptcy depending on when they were made and how indebted individuals were at the time the loan was made - an approach used in French bankruptcy procedure. A pre-determined debt schedule could be adopted based on the borrowing behavior of rational consumers at given levels of income and other characteristics. All debt in excess of the scheduled amount would be discharged in bankruptcy and, if a debtor had multiple loans from different creditors, then loans would be ranked in chronological order and the most recent loans would be discharged first. This approach would discourage lenders from lending more to hyperbolic discounters than they lend to otherwise similar rational consumers, since the additional loans would be discharged in bankruptcy more often.

\section{Coordinating Bankruptcy with Other Policy Tools}

Both bankruptcy law and banking regulations affect credit markets, so that when the bankruptcy system shifts in a pro-creditor direction, other types of regulation could be changed so as to provide additional protection to debtors. A number of researchers have proposed changes in banking regulations and truth-in-lending laws that would reduce the supply of credit to the most vulnerable debtors.

Ronald Mann (2006) discusses a number of possible changes in regulation of credit card loans. One proposal would require that purchases made using credit cards be subject to a surcharge, which would encourage consumers to use cash rather than credit. Another is to restrict or ban rewards programs that encourage spending by credit card holders. Another would be to require lenders to raise their minimum monthly payment levels, so that debtors would be required to repay more of the amount owed each month. This would both reduce the amount of interest that debtors pay and force debtors to reduce their consumption before they accumulate as much debt. ${ }^{15}$ Credit bureaus could

\footnotetext{
${ }^{15}$ Federal regulators do not directly regulate credit card loan terms, but they issue "guidances" to lenders that are generally followed. In 2005, a guidance was issued recommending that credit card lenders raise
} 
also be prohibited from selling information about individual consumers' credit records without their consent, which would reduce or eliminate the practice of lenders mailing out unsolicited card offers. Finally, the marketing of credit cards to minors and college students could be more tightly restricted.

Truth-in-lending laws could also be extended to require that consumers receive additional information concerning their credit card loans. Senator Christopher Dodd introduced legislation in 2004 that would require credit card lenders to inform consumers each month how long it will take to repay their loans if they make only the minimum payment. Mann (2006) proposed that credit card issuers be required to give consumers additional information each time they use their cards; the information could include whether the purchase will trigger a penalty for exceeding the credit limit and how much interest consumers will pay if the purchase adds to their credit card debt.

Finally, Posner (1995), Rougeau (1996), Bar-Gill (2004), Peterson (2004), and Mann (2006) consider abolishing the Marquette decision and allowing states to reintroduce usury limits on interest rates (although they do not all go so far as to advocate this change ). While binding usury limits would reduce the amount that hyperbolic discounters can borrow, they have the drawback that they could drive hyperbolic discounters and other risky debtors to borrow from "payday" lenders, pawnbrokers, and rent-to-own stores, which charge annual interest rates in the range of 400 to 500 percent.

The unifying theme of these proposals is that when bankruptcy is caused by rational borrowers who suffer adverse events, the issues are fairly straightforward to analyze and to resolve. But when bankruptcy results from overborrowing on the part of hyperbolic discounters that eventually grows into severe financial distress, just moving the rules of bankruptcy in a pro-creditor direction is at best a very partial answer. Instead, an appropriate policy response to this kind of overborrowing must both discourage hyperbolic discounters from borrowing too much and penalize lenders who take advantage of hyperbolic discounters' tendency to overborrow.

their monthly minimum payments so that negative amortization could not occur. Most issuers responded by increasing their minimum payment levels to the previous month's interest and fees plus one percent of the principle. See Mann (2006). 


\section{References}

Ashcraft, Adam, Astrid A. Dick, and Donald P. Morgan, “The Bankruptcy Abuse Prevention and Consumer Protection Act: Means-Testing or Mean Spirited? working paper (2006).

Ausubel, Lawrence M. "The Failure of Competition in the Credit Card Market," The American Economic Review, vol. 81:1, pp. 50-81 (1991).

Ausubel, Lawrence M., "Adverse Selection in the Credit Card Market," University of Maryland working paper, June 1999.

Ausubel, Lawrence M., "Credit Card Defaults, Credit Card Profits, and Bankruptcy," American Bankruptcy Law Journal, vol. 71, p. 249 (1997).

Bar-Gill, Oren. "Seduction by Plastic," Northwestern Law Review, vol. 98, p.1373 (2004).

Barron, John M., Michael E. Staten, and Stephanie M. Wilshusen, "The Impact of Casino Gambling on Personal Bankruptcy Filing Rates," Contemporary Economic Policy (2002).

Berkowitz, Jeremy, and Richard Hynes, "Bankruptcy exemptions and the market for Mortgage Loans," J. of Law and Economics, vol. 42, pp. 809-830 (1999).

Caplovitz, David, Consumers in Trouble: A Study of Debtors in Default. New York: The Free Press (1974).

Coleman, Peter J., Debtors and Creditors in America. State Historical Society of Wisconsin (1974).

Domowitz, Ian, and Sartain, Robert L., "Determinants of the Consumer Bankruptcy Decision," J. of Finance, vol. 54(1), pp. 403-20 (1999).

Dranove, David, and Michael L. Millenson, "Medical Bankruptcy: Myth versus Fact," Health Affairs (online edition), vol. 25(2): w74-w83 (2006).

Durkin, Thomas, "Credit Cards: Use and Consumer Attitudes, 1970-2000," Federal Reserve Bulletin, pp. 623-634 (September 2000).

Efrat, Rafael. "Global Trends in Personal Bankruptcy," American Bankruptcy Law Journal, vol. 76, pp. 81-110 (2002).

Elias, Stephen. 2006. The New Bankruptcy: Will it Workfor You? Nolo Press (2006).

Ellis, Diane. "The Effect of Consumer Interest Rate Deregulation on Credit Card Volumes, Charge-Offs, and the Personal Bankruptcy Rate," Bank Trends, No. 98-05 
(1998).

Evans, David S., and Richard Schmalensee. Paying with Plastic: The Digital Revolution in Buying and Borrowing. Cambridge: MIT Press (1999).

Fan, Wei, and Michelle J. White. "Personal Bankruptcy and the Level of Entrepreneurial Activity." Journal of Law \& Economics, vol. 46:2, pp. 543-568 (2003).

Fay, Scott, Erik Hurst, and Michelle J. White. "The Household Bankruptcy Decision," American Economic Review, vol. 92:3, pp. 708-718 (2002).

Flynn, Ed, and Gordon Bermant. "Bankruptcy by the Numbers: Credit Card Debt in Chapter 7 Cases," American Bankruptcy Institute Journal. vol. 22, p. 20 (Dec. 2003/Jan. 2004).

Flynn, Ed, and Gordon Bermant. "Bankruptcy by the Numbers: A Tale of Two Chapters: Financial Data," American Bankruptcy Institute Journal, vol. 21, p. 20 (2002).

Gropp, Reint, J. Karl Scholz and Michelle J. White, "Personal Bankruptcy and Credit Supply and Demand," Quarterly Journal of Economics, vol. 112, pp. 217-251 (1997).

Gross, David B., and Nicholas S. Souleles, "An Empirical Analysis of Personal Bankruptcy and Delinquency," Review of Financial Studies, vol. 15(1), pp. 319-47 (2002).

Gross, David B., and Nicholas S. Souleles, "Do Liquidity Constraints and Interest Rates Matter for Consumer Behavior? Evidence from Credit Card Data," Quarterly J. of Econ. vol. 117, pp. 149-? (2002).

Himmelstein, David U., Elizabeth Warren, Deborah Thorne, and Steffie Woolhandler, "Illness and Injury as Contributors to Bankruptcy," Health Affairs (online edition), vol. 24, pp. w5-63-w5-73 (Feb. 2, 2005).

Johnson, Kathleen W., "Recent Developments in the Credit Card Market and the Financial Obligations Ratio,” Federal Reserve Bulletin, pp. 473-486 (Autumn 2005).

Kilborn, Jason J., "La Responsabilisation de l'Economie: What the United States Can Learn from the New French Law on Consumer Indebtedness," Michigan Journal of International Law, vol. 26, p. 619 (2005).

Kilborn, Jason J., "The Innovative German Approach to Consumer Debt Relief: Revolutionary Changes in German Law, and Surprising Lessons for the United States," Northwestern Journal of International Law and Business, vol. 24, p. 257 (2004).

Laibson, David, "Golden Eggs and Hyperbolic Discounting," Quarterly J. of Econ., vol.112, pp.443-477 (1997). 
Laibson, David, Andrea Repetto, and Jeremy Tobacman, "A Debt Puzzle," in Knowledge, Information, and Expectations in Modern Macroeconomics: In Honor of Edmund S. Phelps (Philippe Aghion et al, eds.) (2003).

Lin, Emily Y., and Michelle J. White, "Bankruptcy and the Market for Mortga ge and Home Improvement Loans,“ Journal of Urban Economics, vol. 50:1, pp. 138-162 (2001).

Livshits, Igor, James MacGee, and Michele Tertilt, "Accounting for the Rise in Consumer Bankruptcies," working paper, (2006).

Mann, Bruce H., Republic of Debtors, Harvard University Press (2002).

Mann, Ronald J., Charging Ahead, Cambridge University Press (2006).

Mann, Ronald J. "Bankruptcy Reform and the 'Sweat Box' of Credit Card Debt." Univ. of Illinois Law Review, vol. 2007:1, 375-404 (2007).

Martin, Nathalie. J.K. Lasser's The New Bankruptcy Law \& You. Wiley \& Sons (2006).

Moss, David A., and Gibbs A. Johnson. "The Rise of Consumer Bankruptcy: Evolution, Revolution, or Both?" American Bankruptcy Law Journal, vol. 73, p. 311 (1999).

National Foundation for Credit Counseling," Consumer Counseling and Education under BAPCPA, (2006).

Peterson, Christopher L., Taming the Sharks: Towards a Cure for the High-Cost Credit Market. Akron, Ohio: University of Akron Press (2004).

Posner, Eric A., "Contract Law in the Welfare State: A Defense of the Unconscionability Doctrine, Usury Laws, and Related Limitations on the Freedom to Contract," J. of Legal Studies. vol. 24, pp. 283-319 (1995).

Rougeau, Vincent D., "Rediscovering Usury: An Argument for Legal Controls on Credit Card Interest Rates," Colorado Law Rev., vol. 67, p. 9 (1996).

Staten, Michael, "The Impact of Post-Bankruptcy Credit on the Number of Personal Bankruptcies," working paper 58, Credit Research Center, Krannert School of Management, Pursue University (1993).

Sullivan, Teresa, Elizabeth Warren and Jay Lawrence Westbrook. As We Forgive Our Debtors. Oxford University Press, New York, NY, (1989).

Sullivan, Teresa, Elizabeth Warren and Jay Lawrence Westbrook. The Fragile Middle Class: Americans in Debt. Yale University Press (2000). 
Wang, Hung-Jen, and Michelle J. White. "An Optimal Personal Bankruptcy System and Proposed Reforms," Journal of Legal Studies, vol. XXIX:1, pp. 255-286 (2000).

White, Michelle J., "Bankruptcy Law," in Handbook of Law and Economics, edited by A.M. Polinsky and Steven Shavell. Elsevier, 2007. NBER working paper 11536, July 2005.

White, Michelle J., "Why Don't More Households File for Bankruptcy? "Journal of Law, Economics, and Organization, vol. 14:2, pp. 205-231 (1998).

Zhu, Ning, "Household Consumption and Personal Bankruptcy, " working paper, UC Davis (2006).

Ziegel, Jacob, "Philosophy and Design of Contemporary Consumer Bankruptcy Systems: A Canada-United States Comparison," Osgoode Hall Law Journal, vol. 27, p. 205 (1999).

Ziegel, Jacob, "What Can the United States Learn from the Canadian Means Testing System?” Univ. of Illinois Law Review, vol. 2007:1, pp. 195-240 (2007). 


\section{Table 1:}

\section{Non-Business Bankruptcy Filings and Consumer Revolving Debt in the U.S., 1980-2006}

\begin{tabular}{|l|c|c|}
\hline & $\begin{array}{c}\text { Non- } \\
\text { business } \\
\text { bankruptcy } \\
\text { filings }\end{array}$ & $\begin{array}{c}\text { Consumer } \\
\text { revolving } \\
\text { debt per } \\
\text { household } \\
\text { (in 2006\$) }\end{array}$ \\
\hline 1980 & 287,000 & 1,664 \\
\hline 1985 & 341,000 & 2,702 \\
\hline 1990 & 718,000 & 3,943 \\
\hline 1995 & 874,000 & 5,927 \\
\hline 2000 & $1,217,000$ & 7,661 \\
\hline 2001 & $1,452,000$ & 7,782 \\
\hline 2002 & $1,539,000$ & 7,786 \\
\hline 2003 & $1,625,000$ & 7,739 \\
\hline 2004 & $1,563,000$ & 7,742 \\
\hline 2005 & $2,039,000$ & 7,771 \\
\hline 2006 & 598,000 & 7,856 \\
\hline
\end{tabular}

Notes: Bankruptcy filings in the U.S. may be by an individual or a married couple. Bankruptcy filings are taken from http://www.abiworld.org/AM/AMTemplate.cfm?Section=Home\&TEMPLATE=/CM/Co ntentDisplay.cfm\&CONTENTID=35631. 
Table 2:

\section{U.S. Personal Bankruptcy Law Before versus After the Bankruptcy Abuse Prevention and Consumer Protection Act of 2005}

\begin{tabular}{|c|c|c|c|c|c|c|c|}
\hline & $\begin{array}{c}\text { Types of } \\
\text { debt not } \\
\text { discharged }\end{array}$ & $\begin{array}{c}\text { Asset } \\
\text { exemption } \\
(\$)\end{array}$ & $\begin{array}{c}\text { Income } \\
\text { exemption } \\
(\$)\end{array}$ & $\begin{array}{c}\text { Percent of } \\
\text { non- } \\
\text { exempt } \\
\text { income } \\
\text { that } \\
\text { debtors } \\
\text { keep }\end{array}$ & $\begin{array}{c}\text { Repayment } \\
\text { period }\end{array}$ & $\begin{array}{c}\text { Cost of } \\
\text { bank- } \\
\text { ruptcy* }\end{array}$ & $\begin{array}{c}\text { Bank- } \\
\text { ruptcy } \\
\text { punish- } \\
\text { ment }\end{array}$ \\
\hline \multicolumn{8}{|l|}{$\begin{array}{l}\text { Pre- } \\
\text { BAPCPA }\end{array}$} \\
\hline Chapter 7 & $\begin{array}{c}\text { secured } \\
\text { debt, taxes, } \\
\text { some credit } \\
\text { card debt } \\
\text { not } \\
\text { discharged }\end{array}$ & $\begin{array}{c}\text { varies across } \\
\text { states; some } \\
\text { have } \\
\text { unlimited } \\
\text { homestead } \\
\text { exemptions }\end{array}$ & unlimited & N/A & N/A & $\$ 600$ & $\begin{array}{l}\text { repeat } \\
\text { filing not } \\
\text { allowed } \\
\text { for } 6 \text { years }\end{array}$ \\
\hline Chapter 13 & $\begin{array}{l}\text { more types } \\
\text { of debt } \\
\text { discharged } \\
\text { than under } \\
\text { Chapter } 7\end{array}$ & unlimited & $\begin{array}{c}\text { depends on } \\
\text { repayment } \\
\text { plan }\end{array}$ & 0 & $3-5$ years & $\$ 1,600$ & $\begin{array}{l}\text { repeat } \\
\text { filing not } \\
\text { allowed } \\
\text { for } 6 \\
\text { months }\end{array}$ \\
\hline \multicolumn{8}{|l|}{ BAPCPA } \\
\hline Chapter 7 & $\begin{array}{l}\text { less debt } \\
\text { discharged } \\
\text { than pre- } \\
\text { BAPCPA }\end{array}$ & $\begin{array}{l}\text { same as pre- } \\
\text { BAPCPA, } \\
\text { but with new } \\
\text { restrictions } \\
\text { on when } \\
\text { debtors can } \\
\text { use high } \\
\text { homestead } \\
\text { exemptions }\end{array}$ & unlimited & N/A & $\mathrm{N} / \mathrm{A}$ & $\begin{array}{c}\$ 1,800- \\
\$ 2,800 \text { plus } \\
\text { the cost of } \\
\text { educational } \\
\text { mandates } \\
\text { and tax } \\
\text { preparation }\end{array}$ & $\begin{array}{l}\text { repeat } \\
\text { filing not } \\
\text { allowed } \\
\text { for } 8 \text { years }\end{array}$ \\
\hline Chapter 13 & $\begin{array}{c}\text { same as } \\
\text { Chapter } 7\end{array}$ & unlimited & $\begin{array}{l}\text { sum of } \\
\text { three sets } \\
\text { of } \\
\text { allowances } \\
\text { (see text) }\end{array}$ & $100 \% * *$ & 5 years & $\begin{array}{c}\$ 2,700- \\
\$ 3,700 \text { plus } \\
\text { the cost of } \\
\text { educational } \\
\text { mandates } \\
\text { and tax } \\
\text { preparation }\end{array}$ & $\begin{array}{c}\text { repeat } \\
\text { filing not } \\
\text { allowed for } \\
2 \text { years }\end{array}$ \\
\hline
\end{tabular}

*Under BAPCPA, debtors' are required to use all of their non-exempt income to repay, but income is defined as debtors' average income during the six-month period prior to filing. This means that the obligation to repay is a fixed dollar amount, so that debtors keep $100 \%$ of their income above the exemption.

Sources: Elias (2006) and Martin (2006). 
Table 3: Personal Bankruptcy Law in Other Countries

\begin{tabular}{|c|c|c|c|c|c|c|c|}
\hline & $\begin{array}{c}\text { Types of } \\
\text { debt } \\
\text { discharged }\end{array}$ & $\begin{array}{c}\text { Asset } \\
\text { exemption }\end{array}$ & $\begin{array}{c}\text { Income } \\
\text { exemption }\end{array}$ & $\begin{array}{l}\text { Percent of } \\
\text { non- } \\
\text { exempt } \\
\text { income } \\
\text { that } \\
\text { debtors } \\
\text { keep }\end{array}$ & $\begin{array}{l}\text { Repayment } \\
\text { period }\end{array}$ & $\begin{array}{c}\text { Debtors' } \\
\text { cost of } \\
\text { bank- } \\
\text { ruptcy }\end{array}$ & $\begin{array}{l}\text { Bank- } \\
\text { ruptcy } \\
\text { punish- } \\
\text { ment }\end{array}$ \\
\hline France & $\begin{array}{l}\text { all debt } \\
\text { remaining at } \\
\text { the end of the } \\
\text { repayment } \\
\text { period; }\end{array}$ & $\begin{array}{c}\text { modest } \\
\text { household } \\
\text { goods } \\
\text { exempt; } \\
\text { no homestead } \\
\text { exemption }\end{array}$ & $\begin{array}{l}\$ 6,000 \text { for } \\
\text { singles to } \\
\$ 15,000 \text { for } \\
\text { family of } \\
\text { three per } \\
\text { year }\end{array}$ & $\begin{array}{l}\text { falls from } \\
95 \% \text { to } 0 \% \\
\text { when } \\
\text { income } \\
\text { exceeds } \\
\$ 20,000 \text { for } \\
\text { single or } \\
\$ 23,000 \text { for } \\
\text { family of } \\
\text { four }\end{array}$ & $8-10$ years & 0 & $\begin{array}{c}\text { discharge } \\
\text { contingent } \\
\text { on } \\
\text { debtors' } \\
\text { efforts to } \\
\text { find/hold a } \\
\text { job }\end{array}$ \\
\hline Germany & $\begin{array}{l}\text { all debt } \\
\text { remaining at } \\
\text { the end of the } \\
\text { repayment } \\
\text { period; } 25 \% \\
\text { discharged } \\
\text { for "good } \\
\text { behavior" }\end{array}$ & $\begin{array}{c}\text { modest } \\
\text { household } \\
\text { goods } \\
\text { exempt; } \\
\text { no homestead } \\
\text { exemption }\end{array}$ & $\begin{array}{c}\$ 21,000 \text { for } \\
\text { couples, up } \\
\text { to } \\
\$ 38,000 \text { for } \\
\text { families } \\
\text { per year }\end{array}$ & $\begin{array}{c}0 \text { in years } \\
1-3,10 \% \text { in } \\
\text { year } 4 \text { and } \\
15 \% \text { in } \\
\text { year } 5 \text { if } \\
\text { "good } \\
\text { behavior" }\end{array}$ & 6 years & $\begin{array}{c}\text { inter- } \\
\text { mediate }\end{array}$ & $\begin{array}{c}\text { discharge } \\
\text { contingent } \\
\text { on } \\
\text { debtors' } \\
\text { effort to } \\
\text { find/hold a } \\
\text { job; no } \\
\text { discharge } \\
\text { unless the } \\
\text { debtor } \\
\text { completes } \\
\text { repayment } \\
\text { plan }\end{array}$ \\
\hline Canada & $\begin{array}{c}\text { unsecured } \\
\text { and some } \\
\text { secured debt } \\
\text { discharged }\end{array}$ & $\begin{array}{c}\text { homestead } \\
\text { exemptions } \\
\text { vary across } \\
\text { provinces; } \\
\text { the largest is } \\
\$ 40,000\end{array}$ & $\begin{array}{l}\$ 21,000 \text { for } \\
\text { single } \\
\text { person; } \\
\$ 40,000 \text { for } \\
\text { families of } \\
\text { four }\end{array}$ & $50 \%$ & $\begin{array}{c}9 \text { months to } \\
3 \text { years }\end{array}$ & $\$ 1,600$ & $\begin{array}{c}\text { cannot } \\
\text { borrow, } \\
\text { manage a } \\
\text { business, } \\
\text { hold some } \\
\text { public } \\
\text { offices }\end{array}$ \\
\hline $\begin{array}{l}\text { England } \\
\text { and } \\
\text { Wales }\end{array}$ & $\begin{array}{c}\text { most } \\
\text { unsecured } \\
\text { and secured } \\
\text { debts } \\
\text { discharged; } \\
\text { not student } \\
\text { loans and } \\
\text { debt arising } \\
\text { from fraud }\end{array}$ & $\begin{array}{l}\text { household } \\
\text { goods and } \\
\text { pensions } \\
\text { exempt; } \\
\text { homestead } \\
\text { exemption is } \\
£ 1,000\end{array}$ & $\begin{array}{l}\text { "reasonable } \\
\text { domestic } \\
\text { needs" of } \\
\text { bankrupt } \\
\text { and family }\end{array}$ & $50-70 \%$ & $\begin{array}{l}\text { up to } 3 \\
\text { years }\end{array}$ & $\begin{array}{l}\text { low for } \\
\text { liquidation; } \\
£ 1,800 \text { for } \\
\text { repayment } \\
\text { plan }\end{array}$ & $\begin{array}{c}\text { cannot } \\
\text { borrow, } \\
\text { manage a } \\
\text { business, } \\
\text { hold some } \\
\text { public } \\
\text { offices for } \\
3 \text { years }\end{array}$ \\
\hline
\end{tabular}


Notes: France, Germany and Canada require that debtors negotiate with creditors and attempt to arrive at a voluntary repayment plan before filing for bankruptcy. In both France and Germany, judges can impose repayment plans if a majority of creditors consents. Sources: Ziegel (1999) and (2007), Kilborn (2004) and (2005), www.bankruptcycanada.com, and www.insolvency.gov.uk/pdfs/guidanceleafletspdf/guidetobankruptcy.pdf. 